\title{
Chlamydia pneumoniae infection and cerebrovascular disease: a systematic review and meta-analysis
}

\author{
Juan Chen', Meijia Zhu², Gaoting Ma², Zhangning Zhao ${ }^{2}$ and Zhongwen Sun ${ }^{3}$
}

\begin{abstract}
Background: A wealth of published studies have been published on association between Chlamydia pneumoniae (C.pneumoniae) infection and cerebrovascular (CV) disease, but the results were inconsistent. This meta-analysis provides a systematic review of the available evidence from all serological and pathological studies of CV disease and C.pneumoniae.
\end{abstract}

Methods: A comprehensive research was conducted of MEDLINE, EMBASE, CNKI, WanFang technological periodical database and reference lists of articles to identify eligible case-control and cohort studies. Odds radio (OR) was calculated for each study outcome. Random effect model was used as pooling method and publication bias was estimated for the results.

Results: Fifty-two published studies that met criteria were selected. In case control studies, an association between C.pneumoniae infection and CV disease was revealed by serum specific lgG (OR, 1.61; 95\% Cl: 1.34 to 1.94), serum IgA (OR, 2.33; 95\% Cl: 1.76 to 3.08) and PCR technique of C.pneumoniae in peripheral blood cells (OR, 1.90; 95\% Cl: 1.17 to 3.07). No significant association was found in serum anti-C.pneumonae IgM seropositivity or in-situ-detection of C.pneumoniae in arterial biopsies with CV disease. Subgroup analysis by available studies suggested that C.pneumoniae may paly a role in atherosclerotic stroke, but be less significant in stroke of cardioembolism or other etiologies.

Conclusion: Association between C.pneumoniae infection and CV disease depends on the analytical method adopted, which seems stronger with stroke due to large artery atherosclerosis. Establishing a causal relationship between C.peumoniae infection and $\mathrm{CV}$ disease will require more prospective studies with combination of techniques and stratified by etiological subtypes.

Keywords: Chlamydia pneumoniae, Infection, Cerebrovascular disease, Atherosclerosis, Meta-analysis

\section{Background}

Cerebrovascular $(\mathrm{CV})$ disease is one of the major causes of long-term disability and mortality throughout the world. Atherosclerosis is the underlying pathology responsible for $\mathrm{CV}$ disease in developed countries and remains a serious problem in developing nations [1]. Conventional risk factors (eg, hypertension, diabetes, dyslipidemia and smoking) can not completely explain the pathogenesis of this disease and many patients, especially younger patients

\footnotetext{
* Correspondence: zhumeijia1818@gmail.com

${ }^{2}$ Department of Neurology, Affiliated Qianfoshan Hospital of Shandong University, 66 Jingshi Road, Jinan 250014, Shandong province, China Full list of author information is available at the end of the article
}

usually lack these risk factors. Over the past decades, increasing body of evidences demonstrated that chronic viral and bacterial infection contributes to the development of atherosclerotic lesions [2]. C.pneumoniae is one of the mostly implicated pathogens in this process [3-5].

C.pneumoniae, an obligate intracellular gram negative bacterium, disseminates via respiratory secretion, causing about $10 \%$ of community-acquired pneumonia cases and 5\% of bronchitis cases [6]. A study published in 1988 firstly proposed that C.pneumoniae infection was an avoidable cause of coronary heart disease [7]. Subsequently, considerable epidemiological studies implicated C.pneumoniae in atherogenic process of $\mathrm{CV}$ events, based

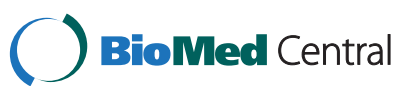


on the evidence from the participation of this pathogen in anti-phospholipids antibody formation, oxidation of LDL, and proliferation of smooth muscle cells $[4,5]$. Clinical trials on the clinical burden of cardiovascular disease under the influence of antibiotic treatment have also been conducted. However, these observations triggered the subsequent publication of several other reports with conflicting results. More recently, a prospective cohort study have linked the combined activity of several infections (i.e. an infection burden), rather than single infection to stroke risk [8]. Therefore, despite the publication of numerous articles on the association, it remains controversial whether C.pneumoniae is an active player or "innocent bystander" for CV disease. Different types of study design and various laboratory tests may largely contribute to the disparate findings. Furthermore, the etiology of $\mathrm{CV}$ disease forms is distinct, it is necessary to investigate evidence of C.pneumoniae infection stratified by different stroke etiologies.

To fill the gap, we performed for the first time this meta-analysis of all eligible studies published before September 2012 to clarify if there is an association between chronic C.pneumoniae infection and CV disease risk; 2) investigate whether the association varies depending on different subtypes of CV disease; 3) evaluate whether the association depend on different materials or laboratory tests.

\section{Methods}

\section{Literature search}

We searched the MEDLINE, EMBASE, CNKI (China National Knowledge Infrastructure) and Wanfang technological periodical database for relevant studies using the following main $\mathrm{MeSH}$ heading: chlamydia pneumoniae, chlamydophyla pneumoniae, atherosclerotic, atherosclerosis, stroke, cerebral ischemic, cerebrovascular, cerebral accident, cerebral apoplexy. An upper date limit was September 2012 and the languages were restricted to Chinese and English. Additional references were identified by reviewing the bibliographies of retrieved articles. After an initial screening of titles and abstracts, only relevant articles remained. The full text of these publications was read to decide whether needed information on the topic of interest was included.

\section{Inclusion criteria}

Articles were eligible if they met the following criteria: 1) the study evaluated the relation between C.pneumoniae infection and CV disease (defined as any fatal or non-fatal ischemic stroke,hemorrhagic stroke or transient ischemic attack); 2) the study had a (nested) casecontrol or cohort design; 3)validated testing tool(s) for detecting C.pneumoniae was used; 4) they reported risk estimate with $95 \%$ confidence interval (CI) or provided sufficient information to calculate. When more than one of the same patient population was included in several publications, only the most recent or complete study was included. No quality scoring was attempted, since the scoring in meta-analyses of observational studies is controversial and has not been internationally accepted to date [9]. Two investigators (Juan Chen and Meijia Zhu) independently selected studies and discrepancies were resolved by consensus.

\section{Data extraction}

For eligible study, the following information was extracted independently by two researchers: first author's name, publication year and country, study design type, average patient characteristics (age and male proportion of cases) within each study, assay methods of C.pneumoniae infection, fully adjusted risk estimate with the corresponding 95\% CI and the adjustment for the main confounding factors. For studies in which risk estimates were reported for more than one set of adjustments, the most adjusted estimate was used. For the studies in which only the number of participants was presented, the unadjusted risk estimates and 95\% CIs were calculated. For the sero-epidemiological studies using microimmunofluorescence (MIF) as test method, the criterion for the antibody cut-off point titer was $1 / 16$ or higher.

\section{Statistical analysis}

We present this meta-analysis following the Meta-analysis of Observational Studies in Epidemiology (MOOSE) statement [9]. The risk estimate as well as its lower and upper CIs were log transformed for odds ratios before conducting the analyses. The pooled value for the effect size (odds radio) was calculated by use of a random effect model using the method of DerSimonian \& Laird [10]. Since heterogeneity could be present as the result of the variety of studies included. Heterogeneity was assessed with the use of the $\mathrm{Q}$ statistic, inconsistency index $\left(\mathrm{I}^{2}\right)$, taking values in the range $0 \sim 100 \%$, whereas $\mathrm{p}$-value $<0.05$ or $\mathrm{I}^{2}>50 \%$ were considered as significant heterogeneity. We performed a subgroup analysis to assess the ORs in patients with stroke of different subtypes according to Trial of Org 10172 in Acute Stroke Treatment (TOAST) criteria. Meta-regression with restricted maximum likelihood (REML) was performed to explore the potentially important covariates: age (mean age in participants) and sex (proportion of males in cases), with the dependent variable being the natural logarithm of the OR from each study. Publication bias was evaluated using funnel plot, Egger's regression and Begger's method. In the presence of publication bias, the non-parametric "trim and fill" method of Duval and Tweedie [11] was applied as a type of sensitivity analysis in order to assess the potential influence of missing studies (if any). All statistical analyses 
were performed using STATA version 11.0 (Stata Corp, College Station, TX). Statistical significance was defined at $\mathrm{p}$ value $<0.05$.

\section{Results}

\section{Identified studies}

Our search initially identified 1151 unique citations, of which the majority were excluded after the first screening of titles and abstracts, and mainly because they were reviews, case-reports, letters or irrelevant to our analysis. After assessing full text of potentially relevant articles, 52 studies published between 1996 and 2012 were enrolled [3-5,8,12-59], comprising 50 (nested) case-control studies and 2 prospective cohort studies. Figure 1 shows a flow diagram describing the study selection process. The majority of studies matched regarding various population characteristics and maximally adjusted estimates from studies were used instead of the raw data or unadjusted ones in some of included studies. The classification of the material was based on the allowable methods of measurement: polymerase chain reaction (PCR) technique, serum antibodies or immunohistochemical method (IHC) against C.pneumoniae. Most of the studies detected serum antibody to define C.pneumoniae infection and report summary statistics, as 12 studies used PCR in peripheral blood cells or IHC in carotid biopsies for validating C.pneumoniae detection. Table 1 and 2 demonstrate the main characteristics of these studies.

\section{Determination of anti-C.pneumoniae IgG in serum}

Forty-two studies - thirty-six cross-sectional, five nested case control studies and one cohort study - compared the association of $\mathrm{CV}$ disease group versus control groups with serum anti-C.pneumoniae IgG titers. The number of $\mathrm{CV}$ cases in the case-control studies ranged from 18 to 483 , with a total of 4240 ; while the number of subjects in control groups ranged from 15 to 483, with a total of 7493. The overall estimated OR of case-control studies based on random effect was 1.61 (95\% CI, 1.34 to 1.94; $\mathrm{p}=0.00)$ and the cross-sectional studies demonstrated a more significant positive association with $\mathrm{OR}=1.74$ (95\% CI, 1.43 to $2.10 ; \mathrm{p}=0.00$ ). The $\mathrm{Q}$ statistic suggested an excessive heterogeneity between case-control studies (p, 0.00), with $\mathrm{I}^{2}=65.9 \%$. Furthermore, sensitivity analysis showed that the results were not affected by sequential exclusion of any particular study. No available methods favored the presence of publication bias. The Begger's test yielded a P-value of $0.83(\mathrm{zc}=1.58)$ and the Egger's fixed effects regression suggested a marginally significant evidence for publication bias $(\mathrm{t}=2.12 ; \mathrm{p}=0.04)$. Forest plot was shown in Figure 2. Funnel plot was shown in Figure 3. Considering the result yielded by Egger's test, we had to conclude that the hypothesis of publication bias could not be further considered as valid. Applying "trim and fill" method to evaluate publication bias obtained a corrected OR $=1.62(95 \%$ CI $: 1.34$ to $1.95 ; \mathrm{p}=0.00$ ), which suggested correction for potential

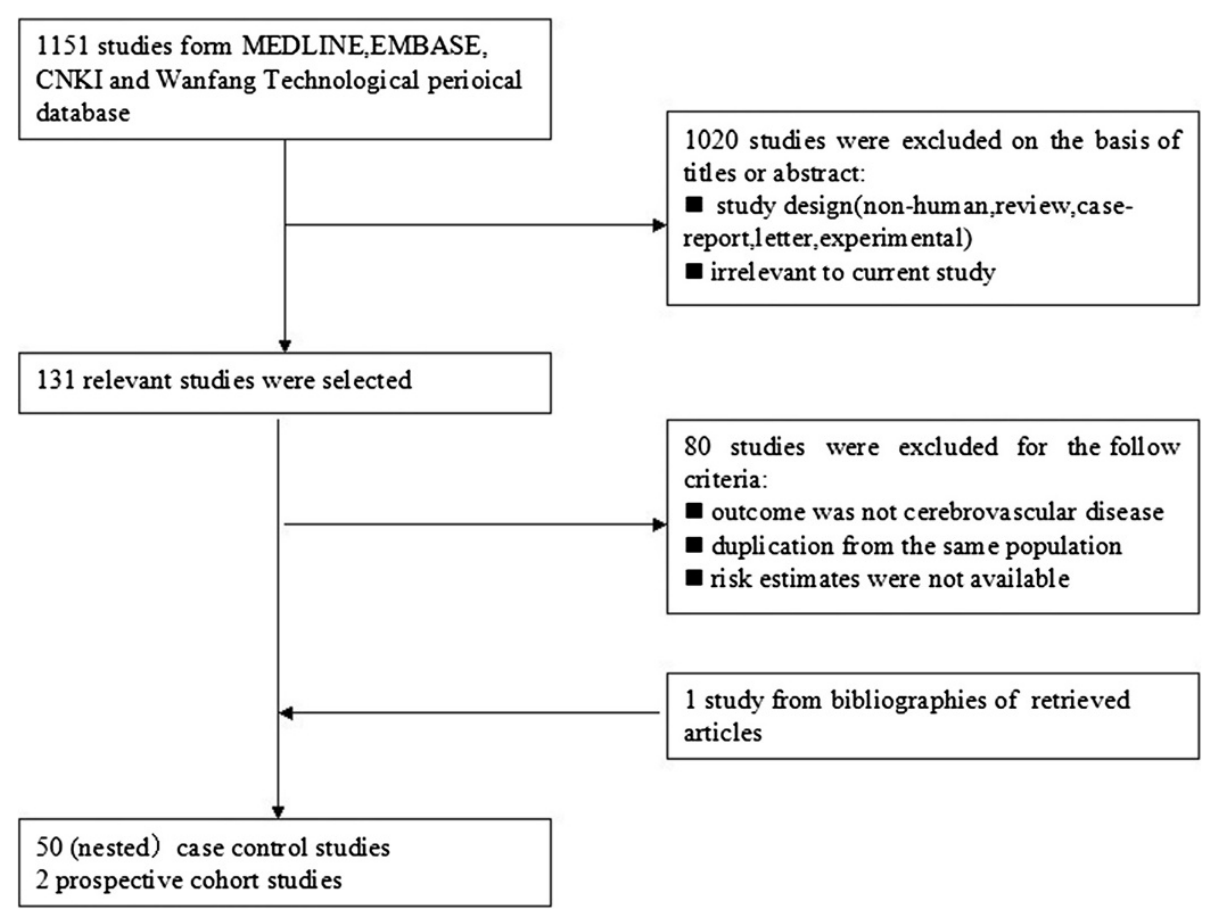

Figure 1 Flow diagram of the study-selection process. 
Table 1 Characteristic of serological studies

\begin{tabular}{|c|c|c|c|c|c|c|c|}
\hline Author Y & Country & $\begin{array}{l}\text { Study } \\
\text { design }\end{array}$ & $\begin{array}{l}\text { Number of } \\
\text { case/control }\end{array}$ & $\begin{array}{l}\text { Case assessment } \\
\text { or endpoint }\end{array}$ & $\begin{array}{l}\text { Serologic } \\
\text { testing assay }\end{array}$ & $\begin{array}{l}\text { Laboratory } \\
\text { test/Marker }\end{array}$ & Adjustment \\
\hline Bandaru VC 2012 & India & $\operatorname{cscC}$ & $100 / 100$ & Ischemic stroke & MIF & $\lg A, \lg G$ & $\begin{array}{l}\text { Age, gender, diabetes, smoking, } \\
\text { hypercholesterolemia, } \\
\text { hyperhomocysteinemia. }\end{array}$ \\
\hline Hasan ZN 2011 & Iraq & $\operatorname{cscC}$ & $50 / 40$ & Ischemic stroke & ELISA & $\lg A, \lg G$ & None \\
\hline Kēnina V 2011 & Latvija & $\mathrm{CsCC}$ & $102 / 48$ & Ischemic stroke & ELISA & $\lg G$ & None \\
\hline Chen YJ 2010 & China & $\operatorname{cscc}$ & $50 / 50$ & Ischemic stroke & MIF & $\lg G$ & None \\
\hline Bandaru VC 2009 & India & $\mathrm{CsCC}$ & $120 / 120$ & Ischemic stroke & MIF & $\lg A, \lg G$ & None \\
\hline Bandaru VC 2009 & India & $\operatorname{cscc}$ & $120 / 120$ & Ischemic stroke & MIF & $\lg A, \lg G$ & None \\
\hline Tiszlavicz Z 2009 & Hungary & $\operatorname{cscc}$ & $280 / 150$ & Ischemic stroke & ELISA & $\lg G$ & None \\
\hline Alavi SM 2009 & Iran & $\operatorname{cscc}$ & $45 / 45$ & Ischemic stroke & ELISA & $\lg G$ & None \\
\hline Bandaru VC 2008 & India & $\operatorname{CsCC}$ & $200 / 200$ & Ischemic stroke & MIF & $\lg A, \lg G$ & $\begin{array}{l}\text { Age, diabetes, smoking, alcoholics, } \\
\text { hypertension, hyperhomocystenemia, } \\
\text { hypercholestemia. }\end{array}$ \\
\hline Lin TM 2008 & China & $\operatorname{CsCC}$ & $450 / 450$ & Ischemic stroke & MIF & $\lg G$ & $\begin{array}{l}\text { Gender, hypertension, diabetes, } \\
\text { hypercholesterolemia, and smoking. }\end{array}$ \\
\hline Hu J 2008 & China & $\operatorname{cscc}$ & $100 / 60$ & $\begin{array}{l}\text { Ischemic stroke, } \\
\text { TIA }\end{array}$ & ELISA & $\lg G$ & None \\
\hline Kis Z 2007 & Hungary & CSCC & $59 / 52$ & Ischemic stroke & ELISA & $\lg A, \lg G$ & Age, gender \\
\hline Alamowitch S 2007 & France & $\operatorname{cscc}$ & $483 / 483$ & Ischemic stroke & MIF & $\lg A, \lg G$ & $\begin{array}{l}\text { Diabetes, smoking, hypertension, total } \\
\text { cholesterol, CHD, season of enrolment. }\end{array}$ \\
\hline Piechowski JB 2007 & Poland & $\operatorname{cscc}$ & $94 / 103$ & Ischemic stroke & ELISA & $\lg A, \lg G$ & Age and gender \\
\hline Chi LQ 2007 & China & $\operatorname{cscc}$ & $50 / 48$ & Ischemic stroke & ELISA & $\lg G$ & None \\
\hline Liu JX 2006 & China & $\mathrm{CsCC}$ & $47 / 48$ & Ischemic stroke & ELISA & $\lg G$ & None \\
\hline Njamnshi AK 2006 & Cameroon & $\operatorname{CscC}$ & $64 / 64$ & $\begin{array}{l}\text { Ischemic stroke, } \\
\text { TIA }\end{array}$ & MIF & $\lg A, \lg G$ & $\begin{array}{l}\text { Diabetes, smoking, hypertension, } \\
\text { obesity and alcohol intake. }\end{array}$ \\
\hline Elkind MS 2006 & USA & $\operatorname{cscc}$ & $239 / 428$ & Ischemic stroke & MIF & $\lg A, \lg G$ & $\begin{array}{l}\text { Age, gender, diabetes, smoking, atrial } \\
\text { fibrillation, hypertension, HDL, LDL and } \\
\text { race. }\end{array}$ \\
\hline Chen L 2006 & China & $\operatorname{cscc}$ & $135 / 135$ & Ischemic stroke & ELISA & $\lg G$ & None \\
\hline Liu AM 2006 & China & CSCC & $80 / 80$ & Stroke & MIF & $\lg A, \lg G$ & None \\
\hline Zhou B 2005 & China & $\mathrm{CsCC}$ & $76 / 80$ & Ischemic stroke & EIA & $\lg A$ & $\begin{array}{l}\text { Age, gender, smoking, alcohol intake, } \\
\text { body weight, hypertension, } \\
\text { cholesterol, hypertention. }\end{array}$ \\
\hline Johsen SP 2005 & Denmark & NCC & $254 / 254$ & Ischemic stroke & ELISA & $\lg A, \lg G$ & $\begin{array}{l}\text { Diabetes, smoking, hypertension, } \\
\text { cholesterol, BMI, alcohol intake, and } \\
\text { education. }\end{array}$ \\
\hline Li FL 2004 & China & $\mathrm{CsCC}$ & $65 / 25$ & Stroke & ELISA & $\lg A, \lg G, \lg M$ & None \\
\hline Anzini A 2004 & Italy & $\operatorname{cscc}$ & $141 / 192$ & Ischemic stroke & MIF & $\begin{array}{l}\lg A, \lg G \\
\lg M\end{array}$ & $\begin{array}{l}\text { Age, gender, CV risk factors and } \\
\text { socioeconomic status. }\end{array}$ \\
\hline Manuela V 2004 & Netherlands & $\operatorname{CscC}$ & $41 / 55$ & Ischemic stroke & ELISA & $\lg A, \lg G$ & $\begin{array}{l}\text { Smoking, hypertension and } \\
\text { hypercholesterolemia. }\end{array}$ \\
\hline Apfalter P 2004 & Australia & $\operatorname{CsCC}$ & $45 / 30$ & Stroke, TIA & MIF & $\lg A, \lg G, \lg M$ & None \\
\hline Carusone CS 2004 & Canada & CsCC & $28 / 24$ & Stroke & MIF & $\lg A, \lg G$ & Age, gender and smoking. \\
\hline Bucurescu G 2003 & USA & $\operatorname{CscC}$ & $25 / 25$ & Stroke, TIA & MIF & $\lg A, \lg G$ & None \\
\hline Ngeh J 2003 & UK & $\operatorname{cscc}$ & $100 / 87$ & Stroke, TIA & ELISA & $\begin{array}{l}\lg A, \lg G \\
\lg M\end{array}$ & $\begin{array}{l}\text { Age, gender, smoking, diabetes, } \\
\text { hypertension, CHD. }\end{array}$ \\
\hline Kawamoto R 2003 & Japan & $\operatorname{CscC}$ & $40 / 85$ & Ischemic stroke & ELISA & $\lg G$ & None \\
\hline Sirmatel F 2003 & Turkey & $\operatorname{cscc}$ & $26 / 53$ & Ischemic stroke & MIF & $\lg G$ & None \\
\hline Zou R 2003 & China & $\operatorname{cscc}$ & $112 / 50$ & Stroke & ELISA & $\lg M, \lg G$ & None \\
\hline
\end{tabular}


Table 1 Characteristic of serological studies (Continued)

\begin{tabular}{|c|c|c|c|c|c|c|c|}
\hline Wolf SC 2003 & Germany & $\operatorname{CsCC}$ & $30 / 116$ & Ischemic stroke & ELISA & $\lg A, \lg G$ & $\begin{array}{l}\text { Age, gender, diabetes, match for other } \\
\text { risks factors. }\end{array}$ \\
\hline Sessa R 2003 & Italy & $\operatorname{CSCC}$ & $18 / 33$ & Ischemic stroke,TIA & MIF & $\lg A, \lg G$ & None \\
\hline Smiega M 2003 & Canada & NCC & 107/3061 & Stroke & MIF & $\lg A, \lg G$ & $\begin{array}{l}\text { Age, gender, diabetes, smoking, } \\
\text { hypertension, and hypercholesterolemia. }\end{array}$ \\
\hline Tanne D 2003 & Israel & NCC & $134 / 134$ & Ischemic stroke & ELISA & $\lg A, \lg G$ & Diabetes, smoking, BMI, hypertension. \\
\hline Katie A C 2003 & Australia & PC & $119 / 1493$ & Stroke & MIF & $\lg A, \lg G$ & $\begin{array}{l}\text { Age, gender, diabetes, smoking, BMI, } \\
\text { hypertension, cholesterol, TG, } \\
\text { hemoglobin and systolic blood pressure. }\end{array}$ \\
\hline Gerdes v 2002 & Netherlands & NCC & $26 / 273$ & Ischemic stroke & ELISA & $\lg A, \lg G$ & None \\
\hline Madre JG 2002 & Spain & $\operatorname{CsCC}$ & $91 / 112$ & Ischemic stroke & MIF & $\lg A$ & None \\
\hline Tarnacka B 2002 & Poland & CSCC & $20 / 15$ & $\begin{array}{l}\text { Sympotomatic } \\
\text { carotid disease }\end{array}$ & ELISA & $\lg G$ & None \\
\hline LaBiche R 2001 & USA & CSCC & $36 / 55$ & $\begin{array}{l}\text { Sympotomatic } \\
\text { carotid disease }\end{array}$ & MIF & $\begin{array}{l}\lg A, \lg G \\
\lg M\end{array}$ & None \\
\hline Katsenis C 2001 & Greece & $\operatorname{CSCC}$ & $20 / 15$ & $\begin{array}{l}\text { Sympotomatic } \\
\text { carotid disease }\end{array}$ & ELISA & $\lg M$ & None \\
\hline Elkind MS 2000 & USA & CSCC & $89 / 89$ & Ischemic stroke & MIF & $\lg A, \lg G$ & $\begin{array}{l}\text { Diabetes, smoking, hypertension, } \mathrm{HDL} \text {, } \\
\text { education, match for age, gender, race. }\end{array}$ \\
\hline Glader CA 1999 & Sweden & NCC & $97 / 197$ & Ischemic stroke & MIF & $\lg A, \lg G$ & $\begin{array}{l}\text { Diabetes, smoking, BMI, hypertension, } \\
\text { hypercholesterolmia. }\end{array}$ \\
\hline Wimmer MLJ 1996 & Germany & $\operatorname{CSCC}$ & $58 / 52$ & Ischemic stroke,TIA & MIF & $\lg A, \lg G$ & Age, gender, hypertension, migraine. \\
\hline
\end{tabular}

CSCC, cross-sectional case control; NCC, nested case control; PC, prospective case-control or cohort; ELISA, enzyme-linked immunosorbent assay;

$\mathrm{MIF}$, microimmunonuorescence; $\mathrm{HDL}$, high density lipoprotein; LDL, low density lipoprotein;TG, triglycerides; CHD, coronary heart disease; BMI, body mass index; TIA, transient ischemic attack; CV, cerebrovascular.

publication bias did not materially alter the combined risk estimate. The one and only cohort study by Katie $\mathrm{AC}$ et al., with sample size of 1612 cases, which was not enrolled in this pooled analysis, reported an $\mathrm{RR}=0.88$ (95\% CI: 0.52 to 1.47 ).

\section{Determination of anti-C.pneumoniae $\lg \mathrm{A}$ in serum}

Thirty-one publications reported data on the association of C.pneumoniae infection and $\mathrm{CV}$ disease based on anti-C.pneumoniae IgA sero-positivity. The number of $\mathrm{CV}$ cases in the case-control studies ranged from 18 to

Table 2 Characteristic of studies using PCR or IHC

\begin{tabular}{|c|c|c|c|c|c|c|c|}
\hline Author Y & Country & $\begin{array}{l}\text { Study } \\
\text { design }\end{array}$ & $\begin{array}{l}\text { Number of } \\
\text { case/control }\end{array}$ & Case assessment & $\begin{array}{l}\text { Detecting } \\
\text { assay }\end{array}$ & Specimen & $\begin{array}{l}\text { Odds ratio } \\
(95 \% \mathrm{Cl})\end{array}$ \\
\hline Gagliardi RJ 2009 & Brazil & $\operatorname{CsCC}$ & $52 / 59$ & Ischemic stroke, TIA & PCR & PBMC/DNA & $0.37(0.01 \sim 9.32)$ \\
\hline Kis Z 2007 & Hungary & $\operatorname{CsCC}$ & $59 / 52$ & Ischemic stroke & PCR & PBMC/DNA & $1.92(0.61 \sim 6.01)$ \\
\hline Apfalter P 2004 & Australia & $\operatorname{CsCC}$ & $45 / 30$ & Stroke, TIA & PCR & PBMC/DNA & $0.65(0.09 \sim 4.89)$ \\
\hline Wang SL 2003 & China & $\operatorname{CsCC}$ & $93 / 90$ & Ischemic storke & PCR & PBMC/DNA & $2.29(1.26 \sim 4.13)$ \\
\hline Müller J 2003 & Denmark & $\operatorname{CsCC}$ & $193 / 368$ & Stroke & PCR & PBMC/DNA & $1.35(0.74 \sim 2.46)$ \\
\hline Sessa R 2003 & Italy & $\operatorname{cscc}$ & $18 / 33$ & Ischemic stroke,TIA & PCR & PBMC/DNA & $5.98(1.68 \sim 21.31)$ \\
\hline Wohlschlaeger J 2005 & German & $\operatorname{cscC}$ & $9 / 23$ & Ischemic stroke & PCR & Carotid plaque/DNA & $2.75(0.15 \sim 49.36)$ \\
\hline Sessa R 2003 & Italy & $\operatorname{CsCC}$ & $18 / 33$ & Ischemic stroke,TIA & PCR & Carotid plaque/DNA & $1.84(0.56 \sim 6.05)$ \\
\hline Katsenis C 2001 & Greece & $\operatorname{CscC}$ & $20 / 15$ & Sympotomatic carotid disease & PCR & Carotid plaque/DNA & $4.19(0.19 \sim 93.97)$ \\
\hline LaBiche R 2001 & USA & $\operatorname{CsCC}$ & $37 / 57$ & Sympotomatic carotid disease & PCR & Carotid plaque/DNA & $0.83(0.26 \sim 2.72)$ \\
\hline Wohlschlaeger J 2005 & German & $\operatorname{CsCC}$ & $9 / 23$ & Ischemic stroke & $\mathrm{IHC}$ & Carotid plaque & $0.14(0.01 \sim 1.27)$ \\
\hline Lastas A 2004 & Lithuania & $\operatorname{CscC}$ & $141 / 59$ & Sympotomatic carotid disease & $\| \mathrm{HC}$ & Carotid plaque & $0.88(0.33 \sim 2.38)$ \\
\hline Neureiter D 2003 & German & CSCC & $20 / 40$ & Ischemic stroke & $\mathrm{HC}$ & Carotid plaque & $9.0(2.32 \sim 34.88)$ \\
\hline Jahromi BS 2003 & Canada & $\operatorname{CsCC}$ & $57 / 13$ & Stoke,TIA & $\mathrm{IHC}$ & Carotid plaque & $0.6(0.18 \sim 2.07)$ \\
\hline
\end{tabular}




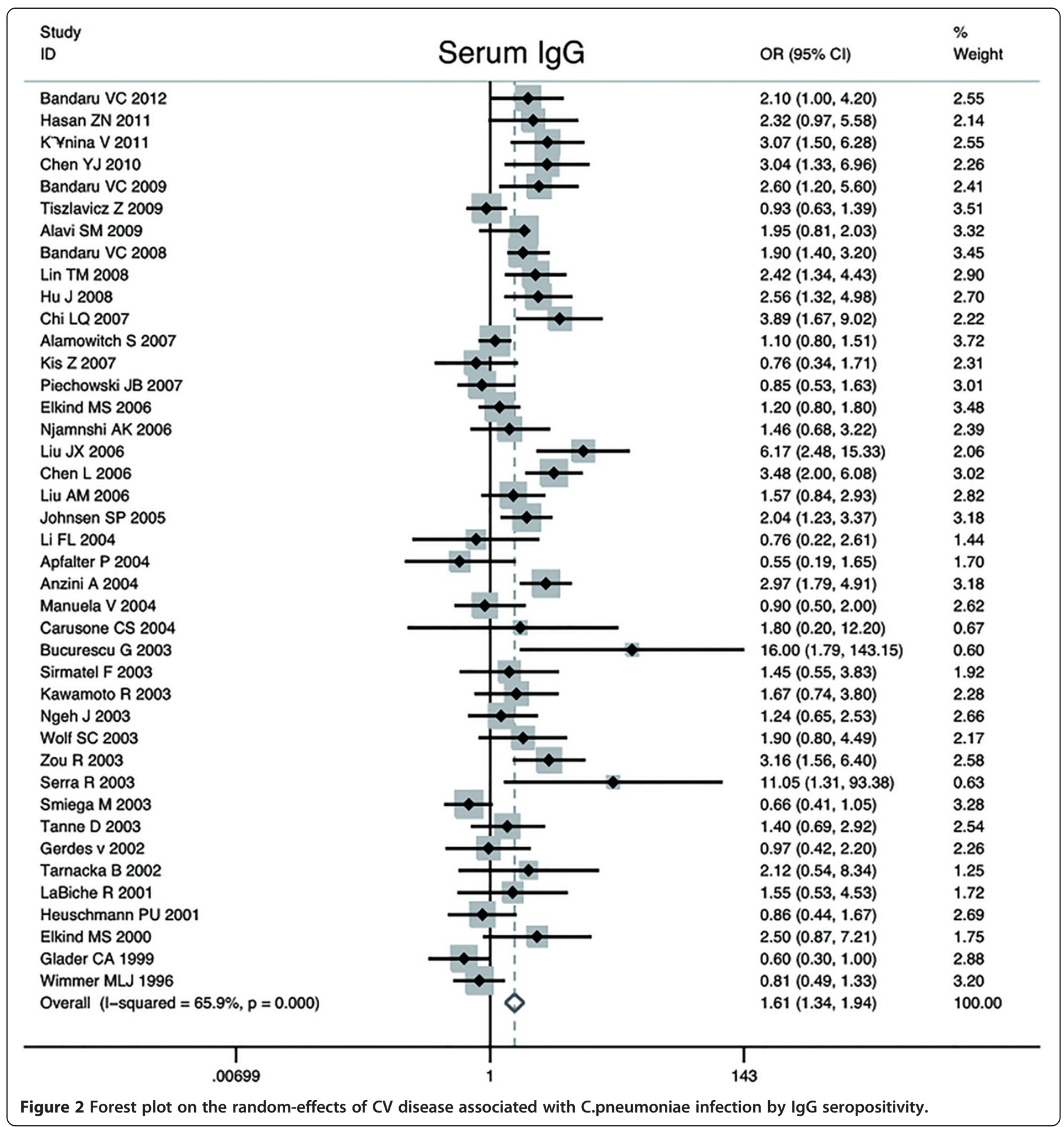

483 , with a total of 2950 ; and the number subjects of control groups ranged from 25 to 483, with a total of 6759. With random effect model, C.pneumoniae infection was statistically associated with an increased risk of $\mathrm{CV}$ events in twenty-nine case-control studies (OR, 2.33; 95\% CI: 1.76 to $3.08 ; \mathrm{p}=0.00)$, and the cross-sectional studies demonstrated a summary OR $=2.87$ (95\% CI: 2.11 to $3.91 ; \mathrm{p}=0.00)$. The heterogeneity between all casecontrol studies was substantial $\left(\mathrm{p}=0.00\right.$; $\left.\mathrm{I}^{2}=70.9 \%\right)$. Furthermore, we observed the result was not affected by exclusion of any specific study from the pooled analysis. Forest plot was shown in Figure 4. Besides, Begger's $(\mathrm{zc}=2.55 ; \mathrm{p}=0.01)$ and Egger's test $(\mathrm{t}=3.15 ; \mathrm{p}=0.00)$ indicated presence of publication bias among those studies. The shape of the funnel plot did reveal some asymmetry (Figure 3). The adjusted pooled estimates by"trim and fill"method was OR 2.33 (95\% CI: 1.76 3.08; $\mathrm{p}=0.00)$, which suggested missing publications did not materially alter the combined risk estimate. The two prospective cohort studies were not included 


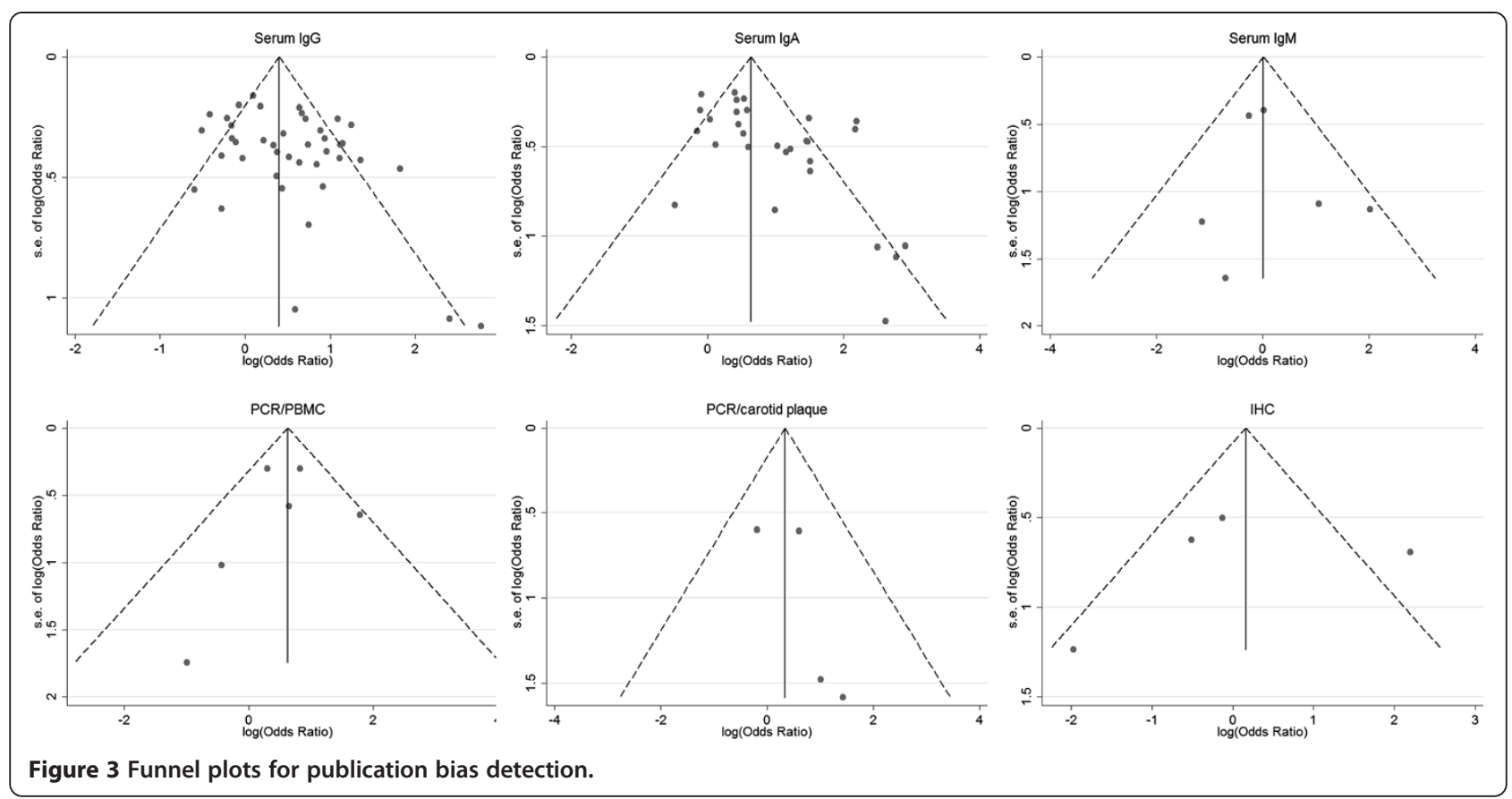

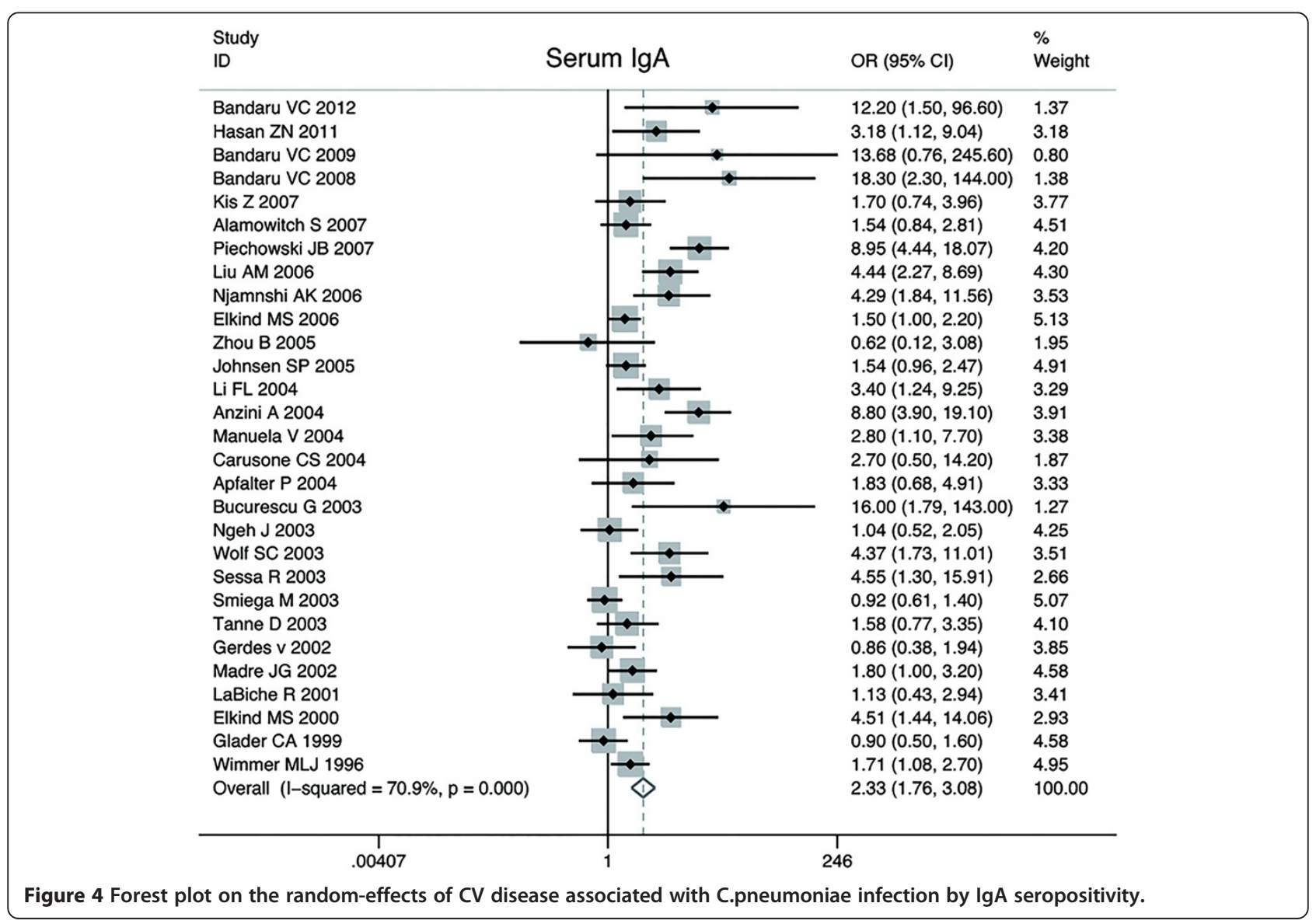




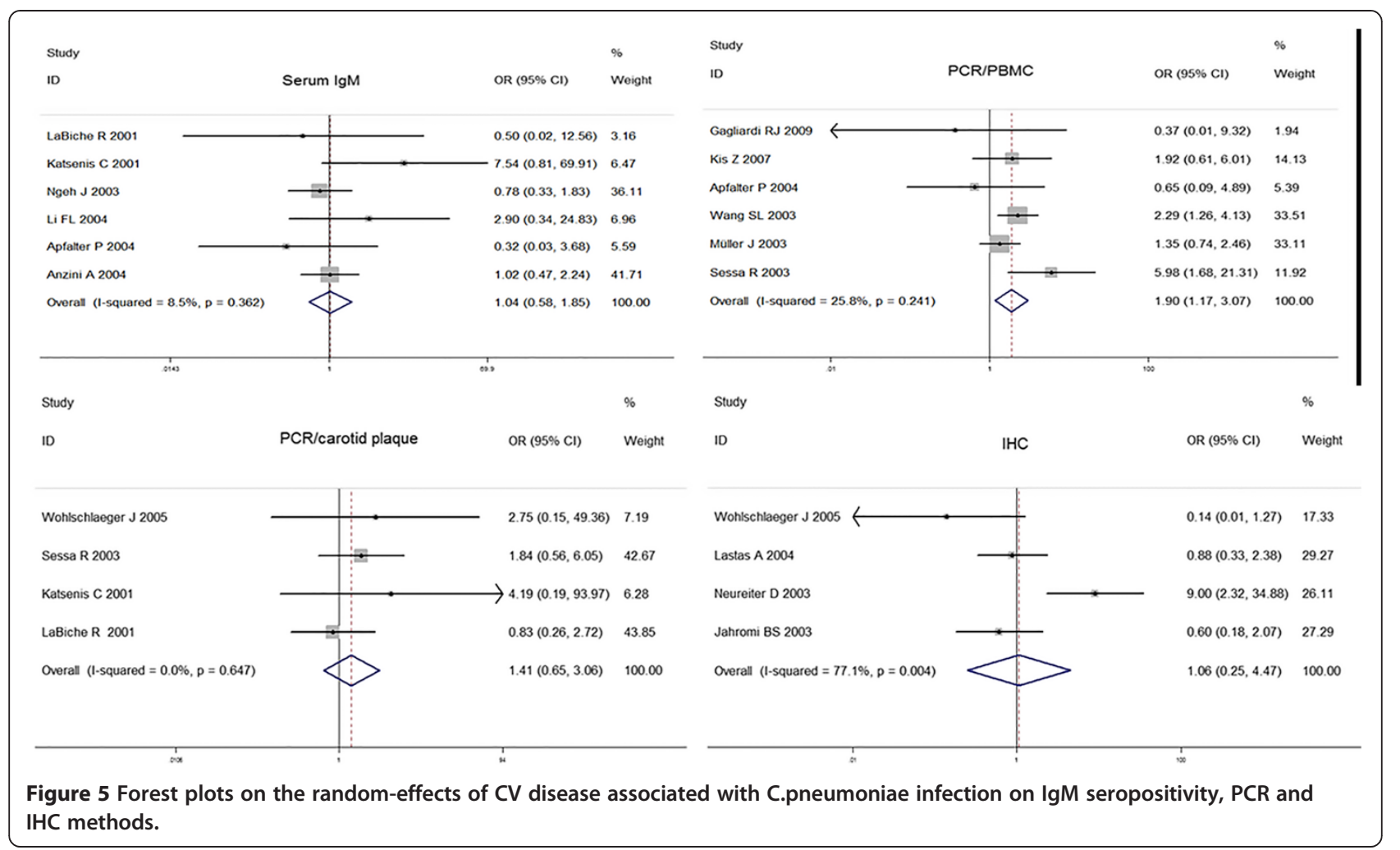

in the pooling analysis: one study (Elkind MS et al.), with a size of 1625 , showed a positive relationship with $R R=1.30$ while the other cohort study (Katie $\mathrm{AC}$ et al.) obtained $\mathrm{RR}=0.67$, suggesting a combined estimate effects on the association between C.pneunoniae infection with $\mathrm{CV}$ disease.

\section{Determination of serum anti-C.pneumoniae IgM}

Serum anti-C.pneumoniae IgM titers were measured in six sero-epidemiologic case-control studies. The number of CV cases in the studies ranged from 20 to 141, with a total of 519; while the number of subjects of control groups ranged from 15 to 192, with a total of 454 . The pooled estimate was 1.02 (95\% CI: 0.47 to 2.24; $\mathrm{p}=0.90)$. No significant heterogeneity was found among the six studies $\left(\mathrm{p}=0.36 ; \mathrm{I}^{2}=8.5 \%\right)$. The Begger's $(\mathrm{zc}=0.00$; $\mathrm{p}=1.00)$ and Egger's tests $(\mathrm{t}=0.54 ; \mathrm{p}=0.62)$ suggested no publication bias, which were in accordance with the funnel plot. The forest plot was shown in Figure 5 and funnel plot was shown in Figure 3.

\section{PCR Detection of C.pneumoniae in PBMC}

In six case-control studies, the peripheral blood cells were collected to detect C.pneumoniae DNA by PCR technique. The size of case groups ranged from 18 to 193 , with a total of 460 ; while the size of control groups ranged from 30 to 368, with a total of 632 . The overall OR for the association of C.pneumoniae with $\mathrm{CV}$ disease based on DNA detection was estimated to be 1.90 (95\% CI: 1.17 to $3.07 ; \mathrm{p}=0.01$ ). The homogeneity was observed among six studies $(\mathrm{p}=0.24$; $\left.\mathrm{I}^{2}=25.8 \%\right)$. The Begger's $(\mathrm{zc}=0.00 ; \mathrm{p}=1.00)$ and Egger's tests $(\mathrm{t}=-0.35 ; \mathrm{p}=0.74)$ did not show any publication bias, and asymmetry did not occur in the funnel plot. The forest plot was shown in Figure 5. Funnel plot was shown in Figure 3.

\section{PCR detection of C.pneumoniae in carotid biopsies}

There were four studies using PCR to detect the bacterium in carotid samples. The total number of samples in case groups was 84 and the number in control groups was 128 . One by Katsenis et al., which obtained the highest OR had the lowest weighting, followed by study by Wohlschlaeger et al. Taken together, the studies reported an OR of 1.41 (95\% CI: 0.65 to $3.06 ; \mathrm{p}=0.39$ ), providing no evidence for a statistically significant association between $\mathrm{CV}$ disease and C.pneumoniae exposure. The studies were homogeneous among the studies $\left(\mathrm{p}=0.64 ; \mathrm{I}^{2}=0.0 \%\right)$. The Begger's and Egger's test supported that the publication bias unlikely $(\mathrm{zc}=1.02, \mathrm{p}=$ $0.31 ; \mathrm{t}=1.34, \mathrm{p}=0.31$ ). The forest plot was shown in Figure 5. Funnel plot was shown in Figure 3.

\section{Immunohistochemical studies}

Four studies, included 227 total events of CV disease and 227 control cases, detected the C.pneumoniae 
antigen using IHC in carotid plaque. The study by Neureiter et al. obtained the highest OR. There was no evidence to support that C.pneumoniae in carotid plaque contributed the CV disease (OR, 1.06; 95\% CI: 0.25 to $4.47 ; \mathrm{p}=0.93)$. The $\mathrm{Q}$ test yields a significant P-value of 0.00 , suggesting a significant heterogeneity with $\mathrm{I}^{2}=77.1 \%$. Moreover, sensitivity analysis showed that the exclusion of any study did not alter the pooled result. Neither the Begger's $(z c=0.34 ; p=0.73)$ nor the Egger's test $(t=-0.31 ; \mathrm{p}=0.79)$ showed any publication bias. The forest plot was shown in Figure 5. Funnel plot was shown in Figure 3.

\section{Subgroup analysis}

There have been some serological studies reporting the results by etiological subtypes of stroke(TOAST criteria: large artery atherosclerosis, cardioembolism, small artery occlusion, other or undefined etiology). In order to exclude the influence of different study methods, the research carried out subanalysis of association between C.pneumoniae infection and CV disease on seropositivity of IgG and IgA, respectively.

Seven studies on seropositivity of anti-C.pneumoniae IgG were included. Subanalysis showed a positive statistically significant result for the $\mathrm{CV}$ cases with large artery disease versus the control (OR, 1.91; 95\% CI: 0.92 to 3.97; $\mathrm{p}=0.08$ ), which was much more significant than ischemic stroke of other etiologies: for cardioembolism(OR, 1.87; 95\% CI: 0.59 to $5.97 ; \mathrm{p}=0.29$ ), for small artery occlusion $(\mathrm{OR}=1.01 ; 95 \% \mathrm{CI}: 0.63 \sim 1.64 ; \mathrm{p}=0.96)$; for other etiology (OR, 0.80; 95\% CI: 0.23 to 2.72; p = 0.72) and for undefined etiology (OR, 1.52; 95\% CI: $0.69 \sim 3.33$; $\mathrm{p}=0.30$ ).

There were five research reports dedicating the relationships between seropositivity of anti-C.pneumoniae IgA and stroke by TOAST criteria. Subanalysis of these studies suggested the advanced OR in large artery atherosclerosis versus control was 2.25 (95\% CI: 1.12 to 4.51; $\mathrm{p}=0.02$ ), which was much more significant than cardioembolism groups (OR, 1.58; 95\% CI: 0.92 to 2.72; $\mathrm{p}=0.10$ ), small artery occlusion (OR, 0.77; 95\% CI: 0.21 to $2.92 ; \mathrm{p}=0.71$ ), other etiology (OR, 1.07; 95\% CI: 0.43 to $2.68 ; \mathrm{p}=0.88$ ) or the undefined etiology (OR, 1.89; 95\% CI: 0.61 to $5.88 ; \mathrm{p}=0.27$ ).

In one study (Neureiter D etc.) using IHC to detect C.pneumoniae infection, all the cases suffered from ischemic stroke of large artery-atherosclerosis according to the TOAST criteria, and it showed a significant association with $\mathrm{OR}=9.0$. The studies detecting C.pneumoniae infection based on serum IgM or by PCR did not investigate the association by stroke subtypes.

\section{Meta-regression on study-level covariates}

In an attempt to explain the large amount of heterogeneity in the sero-epidemiological results, meta-regression was applied, where we attempted to use as explanatory variables, various study-level covariates. We finally considered two potential covariates: proportion of males in cases and the mean age of cases. Unfortunately, multivariate regression demonstrated no significant between the two moderators and only bits of ORs heterogeneity originates from the different age and male percents in each study.

\section{Discussion}

The notion that C.pneumoniae infection may be responsible for atherosclerosis and vascular accidents is not new. Previous meta-analysis just addressed the association between C.pneumoniae and coronary artery disease (CAD) or atherosclerosis based on sero-epidemiologic studies [60]. Even though $\mathrm{CV}$ disease shares many risk factors with CAD because of the underlying atherosclerotic mechanism, it was much more heterogeneous for the comprehensive manifestation and multifactorial etiology. Large amount of studies have identified an apparent linkage between C.pneumoniae infection and CV accidents, as several studies failed to demonstrate consistent associations. The present study was promoted for the absence of any published meta-analysis on the association between C.pneumoniae infection and CV disease. In consideration of the diversity of laboratorial methods and interpretative criteria, we enrolled all available studies to date using different markers of chronic C.pneumoniae infection rather than sero-epidemiological studies only to evaluate the relationship point to point.

\section{Antibody investigation}

Serum antibody detection is the most commonly used assay to diagnose acute or chronic C.pneumoniae infection, including the markers: IgG, IgA and IgM. Each type of immunoglobin has the specific kinetic feature. In primary infection patients, IgM antibody appears about 2 to 3 weeks after the onset of infection and is generally undetectable after 2 to 6 month in serum. IgG antibody does not reach high title until 6 weeks after the onset of illness, with a half-life of weeks to months. In case of reinfection, IgM antibody may not appear and the level of IgG titer increase within a week [61]. Thus, the isolated elevated IgG can only be interpreted as a previous antigenic contact and past infection, with the exception of IgG elevation between two samples or an especially high level in one sample represents a current infection, whereas IgM may not be detectable in specimens in early course of illness or reinfection. IgA has a biological half-life less than 7 days and the presence has been associated with current or chronic infection. Although debated, high IgA titres has been suggested to be a more valid and reliable measure of chronic active infection compared with IgG [18]. 
Studies enrolled in this meta-analysis used ELISA or MIF to detect IgG, IgA or IgM, with the titer cutoff points of $1 / 16$ or higher by MIF. In the meta-analysis of case-control studies, the elevated titer of IgA or IgG showed a significant relationship with $\mathrm{CV}$ disease, while the IgM did not. These findings are consistent with reports that most people have antigenic contact with C.penumoniae early in their lives and that re-infections are the norm, accounting for the absence of IgM in reinfection [62]. There were only two prospective cohort studies published to date evaluating the relation between C.pneumoniae infection and CV disease, while one used ELISA and the other one used MIF as detecting method, obtaining contradictory results by IgA and a negative result by IgG. In general, prospective cohort studies are considered superior to case-control and cross-sectional studies, since prospective studies investigate temporal relations and can indicate whether the exposure variable preceded the outcome variable. In contrast, in crosssectional studies, the potentially causal exposure variable and the outcome variable are determined at the same or close moment, which makes it difficult to distinguish between them, since pneumonia is the most common poststroke infection, which mostly occur in acute phase of stroke [63]. Nevertheless, if participants in prospective studies are infected in the period between blood collection and stroke manifestation, the exposure status will also be misclassified, which leads to excessively underestimation of the relation. After all, despite the statistical significance of the positive association between C.pneumoniae and CV disease, its causal relevance to $\mathrm{CV}$ disease remains uncertain for inadequate literature amount of prospective cohort studies.

\section{PCR studies in PBMC}

Recently, C.pneumoniae DNA detection by PCR technique has been shown to be a valid diagnostic method and apparently more reliable than other methods. C.pneumoniae may localize in atheromatous cardiovascular tissues, peripheral blood monocytes and atheromatous lesions of arteries [52,56]. These organisms and positive monocytes may contribute to total antibody production. PCR test allows the active current infection diagnosis, being negative for the patients previously contaminated and already healed. The presence of circulating DNA of C.pneumoniae may represent a persistent systemic infection, but this method must be performed with great caution to prevent false-positive and falsenegative results. Our evaluation of studies with PCR of PBMC showed that C.pneumoniae DNA confers an odds ratio for CV disease of approximately 1.90 (95\% CI:1.17 to 3.07) and the results of the five studies were homologous. The significant results from sero-epidemiological studies and PCR detection in PMBC all contribute to the hypothesis that a common secondary C.pneumoniae infection eventually leading to atheroma formation and plaque rupture, which is in accordance with previous studies [64].

\section{Tissue diagnosis by PCR and IHC}

C.pneumoniae can directly infected cells of vessel wall, leading to latent residence infection. That is why the DNA and antibody of the pathogen has been identified in atheromatous tissues by use of various methods [4]. The pooled analysis of four studies with PCR on carotid plaque biopsy showed a combined OR, suggesting no significant difference in the prevalence of C.pneumoniae infection between cases and controls. IHC offers the advantage of preserving tissue morphology and permitting localization of the infectious agent to specific areas and tissues. In the four studies using IHC as detecting method, only one showed a strong relationship with a high $\mathrm{OR}=9.0$. Despite this, no significant relationship was found by pooled analysis $(\mathrm{OR}=1.06)$. The discrepancy between the results from peripheral blood and atheromatous plaques may be attributed to several factors. Wohlschlaeger J etc. evaluated different cerebral aortic biopsy in patients with $\mathrm{CV}$ disease and observed the highest C.peneumoniae prevalence using PCR in right cerebral vascular artery (20\%), and lower in carotid artery $(11.1 \%)$ or basilar artery $(10 \%)$. What's more, by IHC, they observed the highest prevalence in the basilar artery $(30 \%)$ and right middle cerebral artery $(30 \%)$, but lowest in the carotid artery (11.1\%) [56]. Thus, it is questionable if bare signals observed from carotid samples reflect systematically the authentic condition of the patients. Another explanation is the fact that both patients with CV disease and control subjects was atherosclerosis, the only difference was whether they were symptomatic. Part of the control subjects have undergone carotid endarterectomy are liable to have advanced atherosclerosis and at the highest risk of current $\mathrm{CV}$ events. After all, the lack of a true gold standard of PCR or IHC technique to date makes it difficult to assess these methods. A recent study, in which C.pneumoniae seroconversion assay and PCR methods were evaluated for diagnosis of C.pneumoniae infection during an outbreak in a military community, suggested that the sensitivity of PCR was lower than that of serologic antibody testing [65].

\section{Association by subgroups of strokes}

Stroke is a disease of different etiologies (i.e., large artery disease, cardioembolism or small vessel disease). Investigations in etiological subtypes of ischemic stroke may help to clarify the possible role of C.pneumoniae in $\mathrm{CV}$ disease, which has only been addressed in studies of small sample size. Previous studies indicated that seropositivity to C.pneumoniae is strongest in patients 
with stroke of large artery atherosclerosis, which contributes to $10 \sim 20 \%$ of strokes, as defined in Acute Stroke Treatment (TOAST) criteria, but less frequent in patients with a stroke due to small-vessel occlusion [66]. In our meta-analysis, this issue was confirmed by seropositivity of IgG and IgA, which is consistent with the hypothesis that C.pneumoniae contributes to atherosclerosis. One of in-situ studies using IHC technique researched the relation by large artery atherosclerosis, and strengthened the relation more [57]. Furthermore, the results also suggested C.pneumoniae might be effective in cardioembolism by elevated serum IgG $(\mathrm{OR}=1.87)$ as well as IgA $(\mathrm{OR}=1.58)$, which deserve more investigation in future studies. Because stroke of cardioembolism results from coronary atherosclerosis in many cases, it is plausible that these patients would also be associated with C.pneumoniae infection. The issue whether C.pneumoniae infection promotes stroke of small vessel disease or other etiology remains questionable for inadequate sample size.

The development of atherosclerotic $\mathrm{CV}$ disease involves a series of steps: initiation, progression, plaque formation, plaque rupture or erosions, and thrombosis. Compelling data indicate that C.pneumoniae infection does contribute to the latter stage of carotid atherosclerosis instead of the earlier stage, since it might promote atherogenesis and eventually trigger acute cardiovascular events $[64,67]$. Some studies also suggested patients infected within a week before the onset of stroke were more likely to develop cerebral infarcts [68]. The pathogen may gain access to the vasculature during local infection and exacerbate atherosclerosis either directly or indirectly. Direct effects include cell lysis, lipid oxidization and proliferation of smooth muscle cells. Indirect systematic effects may involve induction of acute phase proteins expression, establishment of a prothrombotic state and promotion arteriosclerosis by activating monocytes $[69,70]$. Furthermore, C.pneumoniae was suggested to trigger specific cell-mediated immunity within plaques and promote plaques rupture by enhancing the production of matrix-degrading metalloproteinase, which was considered to be responsible for fibrous cap rupture [71]. Activated immune cells also produced cytokines and cytotoxic antibodies, which in turn, lead to the local perpetuation of the vessel wall damage. Further researchers proposed the bacterium act in cooperation with conventional risk factors and genetic predisposition, which insufficient for disease generation alone [56]. Therefore, whether a specific pathogen will initiate or accelerate the complications of atherosclerosis maybe determined by the complex interactions of those complex factors. It would thus appear that further research will be needed before we can predict how C.pneumoniae influence atherogenesis and its potential interaction with other pathogenic factors.
The major strength of our meta-analysis is that we enrolled all available cross-sectional and prospective studies using various detection methods, which enhanced comprehensiveness of the findings and reduced the likelihood of selection bias. However, several limitations should be acknowledged. First, at present, the assessment of chronic active C.pneumoniae infection is difficult and there is no wholly satisfactory method for diagnosis. In this meta-analysis, we defined the diagnosis standard in various approach according to the recommendations from the Centers for Disease Control and Prevention and the Laboratory Centre for Disease Control [61]. Second, heterogeneity in sero-epidemiological studies is substantial. The variability in serum sample dilutions and in the method used by commercial laboratories may partially account for this heterogeneity. It is also recognized that cross-reactivity between C.pneumoniae and other micro-organism may occur in serology. Other possible explanations include small sample sizes, degree of the results adjustment, time of blood collection and stage of the CV disease. In addition, prospective studies typically can provide more information on the clinical relevance. Regrettably, only two prospective cohort studies investigated $\mathrm{CV}$ disease were eligible and yielded contradictory results, thus insufficient to demonstrate a causal relationship on this issue.

\section{Conclusions}

In the present meta-analysis, seropositivity for anti-C. pneumoniae $\operatorname{IgG}, \operatorname{IgA}$ and C.pneumoniae DNA were found significantly associated with increased CV disease in case-control studies, and the serum IgM was not. Meanwhile, data from the present study did not show a significant correlation between $\mathrm{CV}$ disease and in-situ detection of C.pneumoniae in arteries specimens. Thus, the finding or not of an association depends on the method employed. In addition, sub-analysis of available studies showed C.pneumoniae is strongest associated with patients with strokes of large artery atherosclerosis, but less frequent in patients with a stroke due to cardioembolism and no clear association were found for other types of ischemic stroke. In conclusion, assessment of different microbiological technique methods and more prospective cohort studies about various stroke subtypes are needed in future to confirm the causal relationship between C.pneumoniae infection and CV disease.

\section{Competing interests}

The authors declare that they have no competing interests.

\section{Authors' contributions}

CJ: Design Initiation, Methodology, Data collection, Analysis, Manuscript writing. ZMJ: Design, Methodology, Data collection, Quality assessment, Supervision, Manuscript revision. ZZN: Analysis, Manuscript revision. MGT: Methodology, Supervision. SZW: Manuscript revision. All authors read and approved the final manuscript. 


\section{Acknowledgements}

This study was sponsored by the Natural Scientific Foundation of Shandong Province (ZR2010M101, Y2008C124), Science and Technology Development project of Shandong province (2007GGWZ02056). Additional support was provided by Science and Technology Development Projects of Jinan City (201202053)

\section{Author details}

'Department of Nephrology, Affiliated Qianfoshan Hospital of Shandong University, 66 Jingshi Road, Jinan 250014, Shandong province, China. ${ }^{2}$ Department of Neurology, Affiliated Qianfoshan Hospital of Shandong University, 66 Jingshi Road, Jinan 250014, Shandong province, China. ${ }^{3}$ Department of Neurology, Yantai Yuhuangding Hospital, 20 Yudong Road, Yantai 264000, Shandong province, China.

Received: 1 February 2013 Accepted: 12 November 2013 Published: 21 November 2013

\section{References}

1. World Health Organization: The World Health Report 2008:Primary Health Care(Now More Than Ever). Switzerland: World Health Organization; 2008.

2. Heuschmann PU, Neureiter D, Gesslein M, Craiovan B, Maass M, Faller G, Beck G, Neundoerfer B, Kolominsky-Rabas PL: Association between infection with helicobacter pylori and chlamydia pneumoniae and risk of ischemic stroke subtypes: results from a population-based case-control study. Stroke 2001, 32(10):2253-2258.

3. Bandaru VC, Boddu DB, Laxmi V, Neeraja M, Kaul S: Seroprevalence of chlamydia pneumoniae antibodies in stroke in young. Can J Neurol Sci 2009, 36(6):725-730.

4. Hasan ZN: Association of chlamydia pneumoniae serology and ischemic stroke. South Med J 2011, 104(5):319-321.

5. Bandaru VC, Boddu DB, Mridula KR, Akhila B, Alladi S, Laxmi V, Pathapati R, Neeraja M, Kaul S: Outcome of chlamydia pneumoniae associated acute ischemic stroke in elderly patients: a case-control study. Clin Neurol Neurosurg 2012, 114(2):120-123.

6. Burillo A, Bouza E: Chlamydophila pneumoniae. Infect Dis Clin North Am 2010, 24(1):61-71.

7. Saikku P, Leinonen M, Mattila K, Ekman MR, Nieminen MS, Makela PH, Huttunen JK, Valtonen V: Serological evidence of an association of a novel chlamydia, TWAR, with chronic coronary heart disease and acute myocardial infarction. Lancet 1988, 2(8618):983-986.

8. Elkind MS, Ramakrishnan P, Moon YP, Boden-Albala B, Liu KM, Spitalnik SL, Rundek T, Sacco RL, Paik MC: Infectious burden and risk of stroke: the northern Manhattan study. Arch Neurol 2010, 67(1):33-38.

9. Stroup DF, Berlin JA, Morton SC, Olkin I, Williamson GD, Rennie D, Moher D, Becker BJ, Sipe TA, Thacker SB: Meta-analysis of observational studies in epidemiology: a proposal for reporting. Meta-analysis of observational studies in epidemiology (MOOSE) group. JAMA 2000, 283(15):2008-2012.

10. DerSimonian R, Laird N: Meta-analysis in clinical trials. Control Clin Trials 1986, 7(3):177-188.

11. Duval S, Tweedie R: Trim and fill: a simple funnel-plot-based method of testing and adjusting for publication bias in meta-analysis. Biometrics 2000, 56(2):455-463.

12. Chan Carusone S, Smieja M, Molloy W, Goldsmith CH, Mahony J, Chernesky M, Gnarpe J, Standish T, Smith S, Loeb M: Lack of association between vascular dementia and chlamydia pneumoniae infection: a case-control study. BMC Neuro/ 2004, 4(1):15.

13. Bandaru VC, Laxmi V, Neeraja M, Alladi S, Meena AK, Borgohain R, Keerthi AS, Kaul S: Chlamydia pneumoniae antibodies in various subtypes of ischemic stroke in Indian patients. J Neurol Sci 2008, 272(1-2):115-122.

14. Kis Z, Sas K, Gyulai Z, Treso B, Petrovay F, Kapusinszky B, Csire M, Endresz V Burian $K$, Mandi $Y$, et al: Chronic infections and genetic factors in the development of ischemic stroke. New Microbio/ 2007, 30(3):213-220.

15. Alamowitch S, Labreuche J, Touboul PJ, Eb F, Amarenco P: Chlamydia pneumoniae seropositivity in aetiological subtypes of brain infarction and carotid atherosclerosis: a case control study. J Neurol Neurosurg Psychiatry 2008, 79(2):147-151.

16. Piechowski-Jozwiak B, Mickielewicz A, Gaciong Z, Berent H, Kwiecinski H: Elevated levels of anti-chlamydia pneumoniae lgA and IgG antibodies in young adults with ischemic stroke. Acta Neurol Scand 2007, 116(3):144-149.
17. Njamnshi AK, Blackett KN, Mbuagbaw JN, Gumedze F, Gupta S, Wiysonge CS: Chronic chlamydia pneumoniae infection and stroke in cameroon: a case-control study. Stroke 2006, 37(3):796-799.

18. Elkind MS, Tondella ML, Feikin DR, Fields BS, Homma S, Di Tullio MR: Seropositivity to chlamydia pneumoniae is associated with risk of first ischemic stroke. Stroke 2006, 37(3):790-795.

19. Anzini A, Cassone A, Rasura M, Ciervo A, Beccia M, Di Lisi F, Fieschi C: Chlamydia pneumoniae infection in young stroke patients: a case-control study. Eur J Neurol 2004, 11(5):321-327.

20. Voorend M, Faber CG, van der Ven AJ, Kessels F, Bruggeman CA, Lodder J: Chlamydia pneumoniae is a likely risk factor for ischemic stroke in young patients. J Stroke Cerebrovasc Dis 2004, 13(2):85-91.

21. Bucurescu G, Stieritz DD: Evidence of an association between chlamydia pneumoniae and cerebrovascular accidents. Eur J Neurol 2003, 10(4):449-452.

22. Ngeh J, Gupta S, Goodbourn C, Panayiotou B, McElligott G: Chlamydia pneumoniae in elderly patients with stroke (C-PEPS): a case-control study on the seroprevalence of chlamydia pneumoniae in elderly patients with acute cerebrovascular disease. Cerebrovasc Dis 2003, 15(1-2):11-16.

23. Wolf SC, Mayer O, Jurgens S, Vonthein R, Schultze G, Risler T, Brehm BR: Chlamydia pneumoniae IgA seropositivity is associated with increased risk for atherosclerotic vascular disease, myocardial infarction and stroke in dialysis patients. Clin Nephrol 2003, 59(4):273-279.

24. Madre JG, Garcia JL, Gonzalez RC, Montero JM, Paniagua EB, Escribano JR, Martinez JD, Cenjor RF: Association between seropositivity to chlamydia pneumoniae and acute ischaemic stroke. Eur J Neurol 2002, 9(3):303-306.

25. Elkind MS, Lin IF, Grayston JT, Sacco RL: Chlamydia pneumoniae and the risk of first ischemic stroke : the Northern Manhattan stroke study. Stroke 2000, 31(7):1521-1525.

26. Wimmer ML, Sandmann-Strupp R, Saikku P, Haberl RL: Association of chlamydial infection with cerebrovascular disease. Stroke 1996, 27(12):2207-2210.

27. Johnsen SP, Overvad K, Ostergaard L, Tjonneland A, Husted SE, Sorensen HT: Chlamydia pneumoniae seropositivity and risk of ischemic stroke: a nested case-control study. Eur J Epidemiol 2005, 20(1):59-65.

28. Smieja M, Gnarpe J, Lonn E, Gnarpe H, Olsson G, Yi Q, Dzavik V, McQueen $M$, Yusuf S: Multiple infections and subsequent cardiovascular events in the heart outcomes prevention evaluation (HOPE) study. Circulation 2003, 107(2):251-257.

29. Coles KA, Knuiman MW, Plant AJ, Riley TV, Smith DW, Divitini ML: A prospective study of infection and cardiovascular diseases: the busselton health study. Eur J Cardiovasc Prev Rehabil 2003, 10(4):278-282.

30. Tanne D, Haim M, Boyko V, Goldbourt U, Reshef T, Adler Y, Brunner D, Mekori YA, Behar S: Prospective study of chlamydia pneumoniae lgG and IgA seropositivity and risk of incident ischemic stroke. Cerebrovasc Dis 2003, 16(2):166-170

31. Gerdes VE, Verkooyen RP, Kwa VI, de Groot E, van Gorp EC, ten Cate H, Brandjes DP, Buller HR: Chlamydial LPS antibodies, intima-media thickness and ischemic events in patients with established atherosclerosis. Atherosclerosis 2003, 167(1):65-71.

32. Glader CA, Stegmayr B, Boman J, Stenlund H, Weinehall L, Hallmans G, Dahlen GH: Chlamydia pneumoniae antibodies and high lipoprotein(a) levels do not predict ischemic cerebral infarctions. Results from a nested case-control study in Northern Sweden. Stroke 1999, 30(10):2013-2018.

33. Apfalter P, Barousch W, Nehr M, Willinger B, Rotter M, Hirschl AM: No evidence of involvement of chlamydia pneumoniae in severe cerebrovascular atherosclerosis by means of quantitative real-time polymerase chain reaction. Stroke 2004, 35(9):2024-2028.

34. LaBiche R, Koziol D, Quinn TC, Gaydos C, Azhar S, Ketron G, Sood S, DeGraba $\mathrm{TJ}$ : Presence of chlamydia pneumoniae in human symptomatic and asymptomatic carotid atherosclerotic plaque. Stroke 2001, 32(4):855-860.

35. Liu A, Xu J, Xi Z: Serum chlamydia pneunoniae antibodies and high-sentive C-reactive protein in patients with stroke. Zhongguo linchuang Kangfu 2006 , 10(38):85-87.

36. Kenina V, Auce $P$, Millers A: The relationship between seropositivity against chlamydia pneumoniae and stroke and its subtypes in a Latvian population. Medicina (Kaunas) 2011, 47(12):657-660.

37. Chen YJ, Zhang XH, Zou W, Liu SY, Zhang P: Effect of chlamydia pneunoniae infection on serum CRP and HCY in ischemic stroke patients. Guangdong Medical Journal 2010, 31(9):1151-1152.

38. Tiszlavicz Z, Somogyvari F, Kocsis AK, Szolnoki Z, Sztriha LK, Kis Z, Vecsei L, Mandi Y: Relevance of the genetic polymorphism of NOD1 in chlamydia pneumoniae seropositive stroke patients. Eur J Neurol 2009, 16(11):1224-1229. 
39. Alavi SM, Ahmadi F, Abeshtan A: Is Chlamydia pneumoniae seropositivity associated with atherothrombotic cerebrovascular infarction? J Infect Public Health 2009, 2(2):96-99.

40. Lin $\mathrm{TM}$, Chen $\mathrm{CH}, \mathrm{Wu} \mathrm{HL}$, Wang $\mathrm{CH}$, Chen $\mathrm{YL}$, Eng HL: The association of $\mathrm{C}$ (-260)-T polymorphism in CD14 promoter and chlamydia pneumoniae infection in ischemic stroke patients. Am J Clin Pathol 2008, 130(4):595-601.

41. Hu J, Yan YA, Jia TJ: Association of MBL and chlamydia pneunoniae infection with ischemic cerebrovascular disease. Acta Academiae Medicinae Jiangxi 2008, 48(4):86-89.

42. Chi LQ, Wang $P$, Zhang C: The clinical study of relationships between inflammation, chlamydia pneunoniae infection and cerebral infaction. Chin J Postgrad Med 2007, 30(9):14-16.

43. Liu JX, Yan PJ, Mei YW: Association between chlamydia pneunoniae infection and cerebral infaction. Chin J Clin Rehabil 2006, 10(14):94-97.

44. Chen L, Zhou YY, Ma WL, Liu P: Association between high-sensitivity $C$-reaction protein, chlamydia pneunoniae infection and carotid artery atherosclerosis and ischemic stroke. Chin J Geriatr Heart Brain Vessel Dis 2006, 8(5):319-321

45. Liu AM, Xu J, yU ZY: Serum chlamydia pneunoniae antibodies and high-sentitive C-reactive protein in patients with stroke. Chin J Clin Rehabil 2006, 10(38):85-87.

46. Zhou B, Shi JP, Fu LY, Li RB, Cao XH, Yang ZQ, Li H: The statistical analysis of association between serum level of chlamydia pneunonia immunoglobulin A antibody and the attack of ischemic stroke. Chin $J$ Pract Internal Med 2007, 27(4):296-299.

47. FI L: Measurement of antibody to chlamydia pneunoniae in serum of patients with cerebral vascular disease and study of pathogenesis. J Brain Neurol 2004, 12(5):377-378.

48. Kawamoto R, Kajiwara T, Oka Y, Takagi Y: An association between an antibody against chlamydia pneumoniae and ischemic stroke in elderly Japanese. Intern Med 2003, 42(7):571-575

49. Sirmatel F, Neyal Muftuoglu M, Tahtaci N, Neyal A, Sirmatel O, Bulbul B. Chlamydia pneumoniae seropositivity in patients with cerebral ischemic attack with or without silent brain infarcts. Ups J Med Sci 2003, 108(3):205-212.

50. Zhou R, Pan SZ, Lai SH, Huang RH: The correlation between chlamydia pneunoniae and stroke. Clin Med Chin China 2003, 19(10):881-882.

51. Tarnacka B, Gromadzka G, Czlonkowska A: Increased circulating immune complexes in acute stroke: the triggering role of Chlamydia pneumoniae and cytomegalovirus. Stroke 2002, 33(4):936-940.

52. Sessa R, Di Pietro M, Schiavoni G, Santino I, Benedetti-Valentini F, Perna R, Romano S, del Piano M: Chlamydia pneumoniae DNA in patients with symptomatic carotid atherosclerotic disease. J Vasc Surg 2003, 37(5):1027-1031.

53. Katsenis C, Kouskouni E, Kolokotronis L, Rizos D, Dimakakos P: The significance of chlamydia pneumoniae in symptomatic carotid stenosis. Angiology 2001, 52(9):615-619.

54. Gagliardi RJ, Caiaffa-Filho HH: Chlamydia pneumoniae and stroke: is there a direct relationship? Arq Neuropsiquiatr 2009, 67(3A):600-604.

55. Muller J, Moller DS, Kjaer M, Nyvad O, Larsen NA, Pedersen EB: Chlamydia pneumoniae DNA in peripheral blood mononuclear cells in healthy control subjects and patients with diabetes mellitus, acute coronary syndrome, stroke, and arterial hypertension. Scand J Infect Dis 2003, 35(10):704-712.

56. Wohlschlaeger J, Wimmer ML, Nagler DK, Haberl R, Weis S: Identification of chlamydia pneumoniae in intracranial and extracranial arteries in patients with stroke and in controls: combined immunohistochemical and polymerase chain reaction analyses. Hum Pathol 2005, 36(4):395-402.

57. Neureiter D, Heuschmann P, Stintzing S, Kolominsky-Rabas P, Barbera L, Jung A, Ocker M, Maass M, Faller G, Kirchner T: Detection of chlamydia pneumoniae but not of helicobacter pylori in symptomatic atherosclerotic carotids associated with enhanced serum antibodies, inflammation and apoptosis rate. Atherosclerosis 2003, 168(1):153-162.

58. Lastas A, Graziene V, Barkauskas E, Salkus G, Rimkevicius A: Carotid artery atherosclerotic plaque: clinical and morphological-immunohistochemical correlation. Med Sci Monit 2004, 10(11):CR606-614

59. Jahromi BS, Hill MD, Holmes K, Hutchison S, Tucker WS, Chiu B: Chlamydia pneumoniae and atherosclerosis following carotid endarterectomy. Can J Neurol Sci 2003, 30(4):333-339.

60. Bloemenkamp DG, Mali WP, Visseren FL, van der Graaf $Y$ : Meta-analysis of sero-epidemiologic studies of the relation between chlamydia pneumoniae and atherosclerosis: does study design influence results? Am Heart J 2003, 145(3):409-417.

61. Dowell SF, Peeling RW, Boman J, Carlone GM, Fields BS, Guarner J, Hammerschlag MR, Jackson LA, Kuo CC, Maass M, et al: Standardizing chlamydia pneumoniae assays: recommendations from the centers for disease control and prevention (USA) and the laboratory centre for disease control (canada). Clin Infect Dis 2001, 33(4):492-503.

62. Bedard L, Paquette N, Cionti Bas M, Aube M, Letourneau J: [The daily public health nursing practice: the montreal infectious diseases unit as an example]. Sante Publique 2004, 16(2):313-328.

63. Westendorp WF, Nederkoorn PJ, Vermeij JD, Dijkgraaf MG, van de Beek D: Post-stroke infection: a systematic review and meta-analysis. BMC Neurol 2011, 11:110.

64. Hedayat DK, Jebeli M, Mandegar MH, Bagheri J, Nabavi SA, Eghtesadi-Araghi P, Mohammadzadeh R, Darehzereshki A, Chitsaz S, Abbasi A: The association between chlamydia pneumoniae DNA in arherosclerotic plaque and major risk factors in patients undergoing coronary artery bypass grafting. Kardiol Pol 2009, 67(9):981-986.

65. Hvidsten D, Halvorsen DS, Berdal BP, Gutteberg TJ: Chlamydophila pneumoniae diagnostics: importance of methodology in relation to timing of sampling. Clin Microbiol Infect 2009, 15(1):42-49.

66. Gan R, Sacco RL, Kargman DE, Roberts JK, Boden-Albala B, Gu Q: Testing the validity of the lacunar hypothesis: the Northern Manhattan stroke study experience. Neurology 1997, 48(5):1204-1211.

67. Sawayama Y, Tatsukawa M, Okada K, Maeda N, Shimizu C, Kikuchi K, Hayashi J: Association of chlamydia pneumoniae antibody with the cholesterol-lowering effect of statins. Atherosclerosis 2003, 171(2):281-285.

68. Grau AJ, Buggle F, Ziegler C, Schwarz W, Meuser J, Tasman AJ, Buhler A, Benesch C, Becher H, Hacke W: Association between acute cerebrovascular ischemia and chronic and recurrent infection. Stroke 1997, 28(9):1724-1729.

69. Mousa A, Al-Zaki A, Taha S, Bakhiet M: Induction of interleukin-18 in atherosclerotic patients: a role for chlamydia pneumoniae. Med Princ Pract 2009, 18(2):105-110.

70. Takaoka N, Campbell LA, Lee A, Rosenfeld ME, Kuo CC: Chlamydia pneumoniae infection increases adherence of mouse macrophages to mouse endothelial cells in vitro and to aortas ex vivo. Infect Immun 2008, 76(2):510-514.

71. Kalayoglu MV, Libby P, Byrne Gl: Chlamydia pneumoniae as an emerging risk factor in cardiovascular disease. JAMA 2002, 288(21):2724-2731.

doi:10.1186/1471-2377-13-183

Cite this article as: Chen et al.: Chlamydia pneumoniae infection and cerebrovascular disease: a systematic review and meta-analysis. $B M C$ Neurology 2013 13:183.

\section{Submit your next manuscript to BioMed Central and take full advantage of:}

- Convenient online submission

- Thorough peer review

- No space constraints or color figure charges

- Immediate publication on acceptance

- Inclusion in PubMed, CAS, Scopus and Google Scholar

- Research which is freely available for redistribution 